\title{
The absence of aldehyde dehydrogenase I Al-positive cells in benign mammary stroma is associated with risk factors for breast cancer
}

This article was published in the following Dove Press journal:

Breast Cancer - Targets and Therapy

27 May 2016

Number of times this article has been viewed

\author{
Björn Logi Isfoss ${ }^{1-3}$ \\ Bo Holmqvist ${ }^{1,4}$ \\ Helena Jernström' \\ Per Alm' \\ Håkan Olsson ${ }^{1,5}$ \\ 'Department of Oncology and \\ Pathology, Department of Clinical \\ Sciences Lund, Lund University, \\ ${ }^{2}$ Department of Pathology, Skane \\ University Hospital, Lund, Sweden; \\ ${ }^{3}$ Department of Pathology, Telemark \\ Hospital, Skien, Norway; ${ }^{4}$ ImaGene-iT \\ $A B$, Medicon Village, ${ }^{5}$ Division of \\ Cancer Epidemiology, Department \\ of Clinical Sciences, Lund University, \\ Lund, Sweden
}

\begin{abstract}
In this study, aldehyde dehydrogenase 1 (ALDH1)-expressing cells in stroma of histologically normal breast tissue from premenopausal women were investigated in situ regarding cellular morphology, cell distribution, and relation to the additional stem cell markers, CD44 (+) and CD24 (-). These results were correlated with hormonal and genetic risk factors for breast cancer. Triple immunofluorescence labeling was performed on tissues from premenopausal women with a family history of breast cancer, and breast reduction specimens from premenopausal women with no family history of breast cancer were used as a control group. The majority of ALDH1-immunoreactive cells in stroma were spindle-shaped or polygonal, and such cells that were $\mathrm{CD}_{4} 4^{-}$and $\mathrm{CD} 24^{-}$were absent in the breast stroma of a significantly larger number of nulliparous than parous women. A less common morphological type of ALDH1-positive cells in stroma was round or oval in shape, and such cells that were $\mathrm{CD} 44^{+}$and $\mathrm{CD} 24^{-}$were absent in a significant number of women with a family history of breast cancer. The $\mathrm{CD} 44^{+} / \mathrm{CD} 24^{-}$immunophenotype is consistent with stem cells, and the round/oval morphology suggests mesenchymal cells. This study demonstrates that there are two morphologically distinct types of ALDH1-positive cells in histologically benign mammary stroma, and the absence of these cells is correlated with clinical risk factors for breast cancer in premenopausal women.
\end{abstract}

Keywords: mammary glands, human, neoplasms, $B R C A 1$ gene, stem cells, immunohistochemistry

\section{Introduction}

Numerous cell types are present in normal human breast tissue, but their relationship with the risk of breast cancer has not been clarified. Pluripotent stem cells (SCs) and committed SCs (progenitor cells) are necessary for the establishment and replenishment of differentiated cells. SCs are defined by their functional qualities: potential for multilineage differentiation, self-perpetuation, and longevity. ${ }^{1}$ Cell populations with SC features exhibit surface protein antigens that make it possible to identify them by immunophenotype (eg, by flow cytometry and cell sorting or by immunohistochemistry). Al-Hajj et $\mathrm{al}^{2}$ used cell surface marker expression to study breast cancer tissue and described the tumorigenic (cancer SC) phenotype CD44 $/$ CD24-/low lineage-. Ginestier et $\mathrm{al}^{3}$ later reported aldehyde dehydrogenase $1 \mathrm{~A} 1$ immunoreactivity $\left(\mathrm{ALDH}^{+}\right)$to be a more efficient immunophenotype for identifying both benign and malignant SCs and noted that the combined SC immunophenotype $\mathrm{ALDH}^{+} \mathrm{CD}^{+} 4^{+}$ was even more efficient. ALDH1 ${ }^{+}$cells in breast carcinoma tissue have also been found to be associated with adverse prognosis. ${ }^{3,4}$ However, to date, very few studies
Correspondence: Björn Logi Isfoss Department of Pathology, Telemark Hospital, 3710 Skien, Norway

Tel +4747654101

Email isfoss@mac.com 
have provided a cell-level in situ description of SC marker positivity in normal human breast epithelium or stroma. ${ }^{3,5-7}$

In our earlier study, we have described in detail the distribution of ALDH1 ${ }^{+}$cells in non-neoplastic mammary tissue. ${ }^{6}$ In a subsequent investigation, ${ }^{7}$ we also found statistically significant associations between $\mathrm{ALDH}^{+}$ductular cells in premenopausal women and the risk of breast cancer in relation to patient age, family history of breast cancer, BRCA1 mutation status, parity, and hormonal replacement therapy. Although those two studies demonstrated a relationship between $\mathrm{ALDH}^{+}$cells in ductules and the risk of breast cancer, they were performed using only one SC marker, ALDH1, and hence any associations with SCs could not be determined. Furthermore, it was recently reported that ALDH1 and CD44 express histologically and functionally separate SC populations in breast tissue, ${ }^{8}$ and thus a multimarker approach is necessary for this research. In our earlier assessments, $\mathrm{ALDH}^{+}$cell populations in benign mammary stroma were detected but were not evaluated with regard to cancer risk factors. Therefore, in the current study, we investigated associations and correlations between clinical risk factors for breast cancer and $\mathrm{ALDH}^{+}$cells in histologically benign stroma, and we used triple immunofluorescence labeling to determine whether these cells also express CD44 and/or CD24, primarily to obtain a more detailed histological description of stromal cells and their expression of these SC markers. Quantitative data from these assessments were then analyzed for correlation with patient age, contraceptive pill use, parity, family history of breast cancer, and $B R C A 1$ mutation.

\section{Patients and methods Patients}

Premenopausal women were selected from our group's earlier investigation of cancer and noncancer patients with or without risk factors for breast cancer. ${ }^{7}$ Patients with an unknown family history and those with insufficient tissue of good histological quality were excluded. The study was approved by the Research Ethics Committee of Southern Sweden (approvals 11-92 and 349-00). The patients gave written consent to participate in this study.

\section{Histology and immunofluorescence}

Only areas of breast tissue that were histomorphologically normal (ie, benign and without hyperplasia or atypia) were chosen. From each patient, one paraffin-embedded block of formalin-fixed tissue was histologically selected based on maximum number of terminal duct-lobular units (TDLUs). The tissue area of the individual specimens ranged from $48 \mathrm{~mm}^{2}$ to $621 \mathrm{~mm}^{2}$ (median $254 \mathrm{~mm}^{2}$ ). Each block was cut in $3 \mu \mathrm{m}$ sections, which were consecutively collected for hematoxylin and eosin staining, and for immunofluorescence triple labeling. The sections were deparaffinized in the following steps: xylene 3 minutes $\times 2,100 \%$ EtOH 1 minute $\times 2,95 \%$ EtOH 1 minute, $70 \%$ EtOH 1 minute $\times 2$, and distilled water 1 minute $\times 2$. Thereafter, antigen retrieval was performed on the sections in citrate buffer $(10 \mathrm{mM}$ sodium citrate containing 0.05\% Tween 20, pH 6.0; Sigma-Aldrich Co., St Louis, MO, USA) for 10 minutes at $90^{\circ} \mathrm{C}$. The sections were subsequently cooled to room temperature (RT), rinsed twice for 5 minutes in phosphate-buffered saline (PBS; $0.1 \mathrm{M}, \mathrm{pH}$ 7.4; AppliChem, Darmstadt, Germany), and immunolabeled using primary and secondary antibodies at the dilutions as specified in Table 1. The tissue sections were incubated for 20 minutes at RT in PBS containing 0.05\% Triton X-100 (TX; Sigma-Aldrich Co.) and 1\% bovine serum albumin (BSA; Sigma-Aldrich Co.), and then for 3 hours at RT in a mixture of primary antibodies diluted in PBS and 1\% BSA containing $0.05 \%$ TX. Next, the sections were rinsed in PBS containing $0.05 \%$ TX for 5 minutes and then in PBS for 5 minutes, and thereafter incubated for 45 minutes at RT with fluorophoreconjugated secondary antibodies in a mixture diluted in PBS containing $1 \%$ BSA. This was followed by rinsing in PBS-TX for 3 minutes and in PBS for 3 minutes, then incubation in 0.1 $\mu \mathrm{M}$ 4',6-diamidino-2-phenylindole (Sigma-Aldrich Co.) in PBS for 15 minutes, and rinsing twice in PBS for 2 min-

Table I Antibodies used

\begin{tabular}{|c|c|c|c|c|}
\hline $\begin{array}{l}\text { Antigen/antibody (product code) } \\
\text { and host species }\end{array}$ & Target species & Clonality (type) & Working dilution & Source \\
\hline ALDHI AI (6III94), mouse & Antihuman & Monoclonal IgGI & $1: 100$ & BD Biosciences, San Jose, CA, USA \\
\hline CD24 (MA5-I I833), mouse & Antihuman & Monoclonal IgM & $\mathrm{I}: 100$ & Thermo Fisher Scientific, Waltham, MA, USA \\
\hline CD44 (PA5-2।4I9), rabbit & Antihuman & Polyclonal IgG & $\mathrm{I}: 100$ & Thermo Fischer Scientific \\
\hline AF488 (A I I029), goat & Antimouse & $\mathrm{Fab}_{2} \operatorname{lgG~H}+\mathrm{L}$ & $1: 150$ & Thermo Fisher Scientific \\
\hline AF568 (A21043), goat & Antimouse & $\mathrm{IFab}_{2} \mathrm{gM \mu}$ & $\mathrm{I}: 200$ & Thermo Fisher Scientific \\
\hline AF647 (A2 1245), goat & Antirabbit & $\mathrm{Fab}_{2} \operatorname{lgG}(\mathrm{H}+\mathrm{L})$ & $\mathrm{I}: 200$ & Thermo Fisher Scientific \\
\hline
\end{tabular}

Abbreviations: IgG, immunoglobulin G; IgM, immunoglobulin M. 
utes. Finally, the sections were cover slipped and mounted in Pro-Long Gold anti-fade solution (Thermo Fisher Scientific, Waltham, MA, USA).

\section{Immunohistochemical controls}

Specificities and absence of cross-reactivity of the secondary antibodies employed were tested by omitting the primary antibodies in the first labeling step. Slides labeled with a single antibody were examined to ascertain that triple immunolabeled tissue appropriately revealed ALDH1 expression. The same protocol was applied to paraffin-embedded sections of spleen and urinary bladder, as positive controls of CD24 and CD44 labeling, respectively. The ALDH1 labeling pattern in immunofluorescence triple labeling was correlated with chromogenic visualization of ALDH1 labeling in adjacent sections (achieved using EnVision + System-HRP-DAB; Dako Denmark A/S, Glostrup, Denmark) and with previously reported ALDH1 labeling of epithelial structures., ${ }^{3,6,9}$

\section{Microscopy}

Representative triple immunofluorescence-labeled sections were analyzed with a confocal laser scanning microscope (Carl Zeiss AG, Jena, Germany). This was performed to ascertain the specificity of multilabeling of individual antigens, and to determine the location of the antigens in relation to cellular morphology (cell bodies and/or processes) and their possible coexistence in individual cells (Figure 1). Confocal microscopy was used to demonstrate different combinations of cytoplasmic and membrane immunolabeling in cells that had definable morphologies and were located in epithelial and stromal structures. Thereafter, the multilabeling was analyzed in all tissue sections using an epifluorescence microscope (Olympus BX 63, Olympus Corporation, Tokyo, Japan) equipped with specific fluorescence filter cubes for multifluorescence detection. Digital image documentation was achieved with an Olympus DP80 camera and software (Olympus Cellsens Dimension). All immunolabeled sections were screened microscopically in total at a magnification of $200 \times$ for each wavelength channel. Multiple areas from each specimen were photographed digitally for all channels, and the images were merged. All cytoplasmic immunolabeling above background of the control was considered positive, regardless of intensity. The tissue compartments analyzed were TDLU stromal areas, and the labeling was recorded for two morphologically defined cell types: round or oval cells and spindle-shaped or polygonal cells. In triple immunolabeling of ALDH1, CD44, and CD24, the labeling was coded for each morphological cell type: 0 , not evaluable; 1 , not present in the specimen; and 2, present in the specimen.
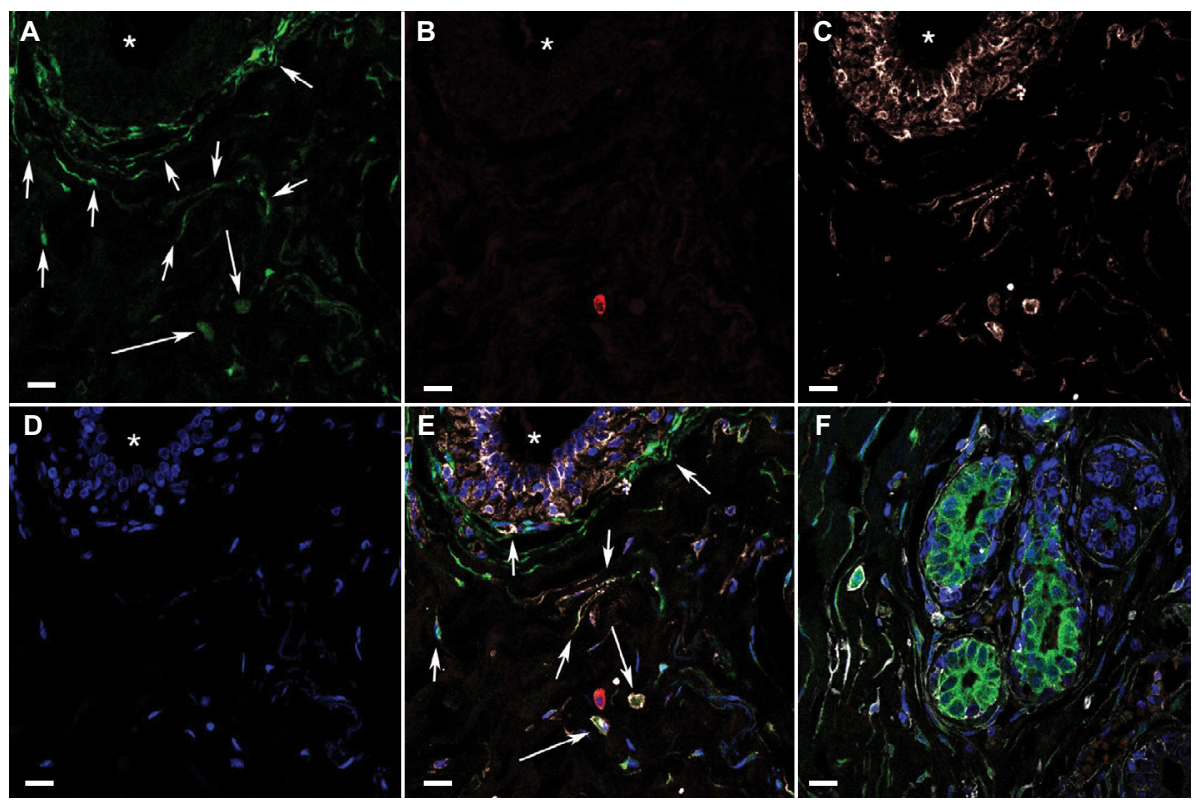

Figure I Confocal microscopy images of triple immunofluorescence-labeled histologically normal breast tissue.

Notes: (A)-(E) Images of single optical sections $(0.6 \mu \mathrm{m}$ thick) from a stromal area with a duct visible in the upper left part of the field $(*$ in lumen), demonstrating immunofluorescence multilabeling and DAPI (nuclear stain) in separate channels. (A) ALDHI, green, indicates the different shaped ALDHI ${ }^{+}$cell types in stroma (round/oval cells [short arrows] and spindle-shaped/polygonal cells [long arrows]). (B) CD24, red, indicates the scarcity of CD24 $4^{+}$cells. (C) CD44, white, indicates the relatively large number of $\mathrm{CD}_{4} 4^{+}$cells, yet many ALDHI ${ }^{+}$CD44- spindle-shaped cells. (D) DAPI, blue. (E) All four channels merged indicate that many ALDHI ${ }^{+}$cells are also CD44 but not $\mathrm{CD} 24^{+}$. Arrows indicate cell types as in (A). (F) Confocal image (merged channels are color coded as in A-E) from a different tissue area showing multilabeled breast tissue containing the stromal cell types as described in $\mathbf{A}-\mathbf{E}$, as well as ductules and numerous adjacent ALDHI ${ }^{+}$CD24- cells with weak membranous CD44 reactivity. Scale bars $=10 \mu \mathrm{m}$.

Abbreviation: DAPI, 4',6-diamidino-2-phenylindole. 


\section{Statistical analysis}

In the statistical evaluations, Fisher's exact test was used for associations and Spearman's rho test for correlations, both were two-tailed, and $P<0.05$ was considered significant. The analyses were performed using SPSS 20.0.0 software (IBM Corporation, Armonk, NY, USA).

\section{Results}

\section{Patients included in the study}

Table 2 provides an overview of the patients who were included in the study, and they were categorized according to risk factors for breast cancer. The material that was ultimately evaluated originated from the following subjects: seven patients with a BRCA1 mutation who underwent surgery for invasive breast carcinoma; ten noncancer patients who underwent mastectomy due to a $B R C A 1$ mutation; four noncancer mammoplasty patients with a family history of breast cancer but no BRCA1/2 mutation; and 19 noncancer mammoplasty patients with no family history of breast cancer (served as normal controls).

\section{Distribution and morphology of ALDHI ${ }^{+}$ stromal cells}

It was observed that the majority of $\mathrm{ALDH}^{+}$cells in TDLUs are located in the stroma, not in the epithelial tree (Figure 2). Cells with the following immunophenotypes were identi-

Table 2 Genetic and hormonal characteristics, and cancer status of the patients

\begin{tabular}{|c|c|c|c|}
\hline $\begin{array}{l}\text { Patient } \\
\text { characteristics }\end{array}$ & $\begin{array}{l}\text { All patients } \\
(n=40)\end{array}$ & $\begin{array}{l}\text { Patients with } \\
\text { a BRCAI } \\
\text { mutation } \\
(n=I 7)\end{array}$ & $\begin{array}{l}\text { Patients with } \\
\text { no BRCAI/2 } \\
\text { mutation } \\
(n=23)\end{array}$ \\
\hline $\begin{array}{l}\text { Age in years, median } \\
\text { (range) }^{\mathrm{a}}\end{array}$ & $28(20-50)$ & $34(23-43)$ & $24(20-50)$ \\
\hline \multicolumn{4}{|l|}{ Parous } \\
\hline Yes & 18 & 12 & 6 \\
\hline No & 20 & 3 & 17 \\
\hline Unknown & 2 & 2 & 0 \\
\hline \multicolumn{4}{|c|}{ Contraceptive pill at the time of surgery } \\
\hline Yes & 13 & 5 & 8 \\
\hline No & 25 & 10 & 15 \\
\hline Unknown & 2 & 2 & 0 \\
\hline \multicolumn{4}{|c|}{ Family history of breast cancer } \\
\hline Yes & 21 & 17 & 4 \\
\hline No & 19 & 0 & 19 \\
\hline Unknown & 0 & 0 & 0 \\
\hline \multicolumn{4}{|c|}{ Synchronous breast cancer } \\
\hline Yes & 7 & 7 & 0 \\
\hline No & 21 & 10 & 23 \\
\hline Unknown & 0 & 0 & 0 \\
\hline
\end{tabular}

Note: ${ }^{\text {aAll }}$ patients were premenopausal. fied most often (given in decreasing order of frequency): $\mathrm{ALDH}_{1}{ }^{+} \mathrm{CD}_{4} 4^{+} \mathrm{CD} 24^{-}$cells, $\mathrm{ALDH} 1^{+} \mathrm{CD}^{-} 4^{-} \mathrm{CD}^{-} 4^{-}$cells, and $\mathrm{ALDH}^{-}{ }^{-} \mathrm{CD} 44^{+} \mathrm{CD} 24^{-}$cells. Distribution of these immunophenotypes varied between the patient groups, which has been detailed in later sections.

\section{$\mathrm{ALDHI}^{+}$spindle-shaped/polygonal and round/oval stromal cell types}

Most ALDH1 ${ }^{+}$cells located in TDLU stroma were spindle shaped or had a polygonal cell body with one or a few cytoplasmic extensions (Figure 3). In many areas, parallel strands of ALDH1 ${ }^{+}$stromal cells were tightly arranged around a single duct, a ductule, or an entire TDLU. In some areas, these cells encircled the periphery of small blood vessels. The highest density of the ALDH1 ${ }^{+}$spindle-shaped/polygonal cell type was at the border between TDLU stroma and generic stroma adjacent to TDLUs. Large quantities of long and thin $\mathrm{ALDH}^{+}{ }^{+}$cytoplasmic processes were detected in many samples, and inasmuch as this appearance corresponded to

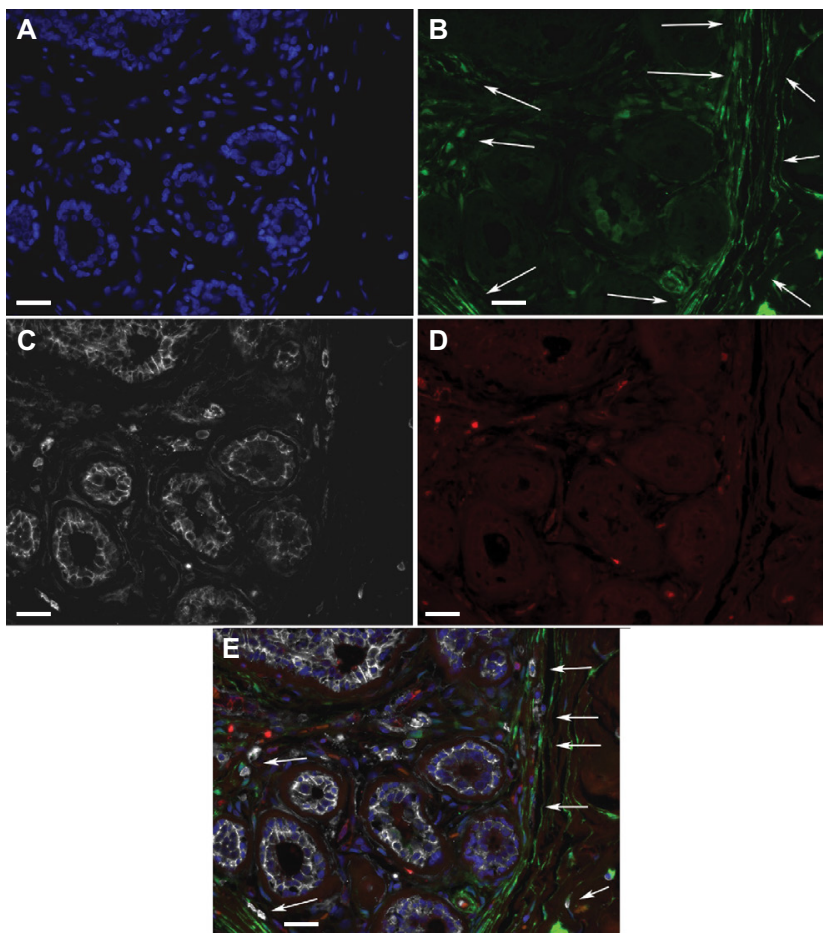

Figure $2 \mathrm{ALDHI}^{+}$cells in TDLUs.

Notes: Fluorescence microscope images of a triple-labeled TDLU from benign breast tissue with the following color coding: (A) DAPI nuclear staining (blue); (B) ALDHI (green); (C) CD44 (white); (D) CD24 (red). (E) A digitally composed image showing all channels merged. Most of the cells located basally in ductules are $\mathrm{ALDH}^{-}$ CD44 $4^{+}$, whereas some adluminal cells are ALDHI ${ }^{+} \mathrm{CD} 44^{+}$and none are $\mathrm{CD} 24^{+}$. In stroma, elongated $\mathrm{ALDHI}{ }^{+}$cells are seen between the ductules, and many such cells are present in the junction between TDLU stroma and generic connective tissue of the breast (arrows). Scale bars $=20 \mu \mathrm{m}$.

Abbreviations: DAPI, 4',6-diamidino-2-phenylindole; TDLUs, terminal ductlobular units. 
the cytoplasmic extensions of cells that exhibited a spindle or polygonal shape, we chose to use the collective term "spindle-shaped/polygonal cells". ALDH1 ${ }^{+}$spindle-shaped/ polygonal cells that were $\mathrm{CD} 44^{+}$or $\mathrm{CD}^{4} 4^{-}$, as well as numerous $\mathrm{ALDH}^{-}{ }^{-} \mathrm{CD} 44^{+}$spindle-shaped/polygonal cells, were identified in one or more TDLUs in almost all the specimens (38/40, 95\%). No CD24+ spindle-shaped/polygonal cells were detected in any specimen.

The morphological definition of $\mathrm{ALDH}^{+}$round/oval cells describes cells in stroma which were round or oval in shape and had small round nuclei and granular cytoplasm (Figure 4). These cells were observed in one or more TDLUs in approximately half of the specimens $(23 / 40,57 \%)$. The presence of $\mathrm{ALDH}^{+}$round/oval cells that were also $\mathrm{CD}^{4} 4^{+}$ varied from $29 \%$ to $63 \%$ between the different risk-factor patient groups.

$\mathrm{CD} 24^{+}$round/oval cells were present in most of the specimens $(33 / 40,82 \%)$, and the majority of these cells were $\mathrm{ALDH}^{-}$and $\mathrm{CD} 44^{+}$. $\mathrm{CD} 24^{+}$round/oval cells that were negative for the other markers were found in a minority of the specimens (14/40, 35\%; Figure 5). ALDH1 ${ }^{+}$round/oval stromal cells that were $\mathrm{CD} 24^{+}$were observed in few specimens $(3 / 40,15 \%)$.

\section{Triple immunofluorescence labeling of the two stromal cell types in relation to clinical risk groups}

Immunofluorescence data for the individual patient risk groups are presented in Table 3 and are described in the following sections.

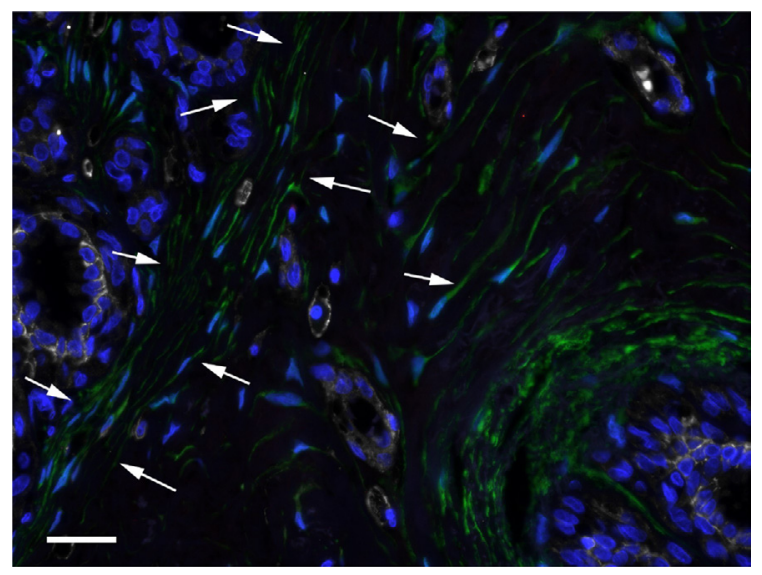

Figure $3 \mathrm{ALDHI}+$ spindle-shaped/polygonal cells in TDLU stroma (arrows). Notes: DAPI nuclear staining (blue), ALDHI (green), CD44 (white), and CD24 (red). Scale bar $=20 \mu \mathrm{m}$.

Abbreviations: DAPI, 4',6-diamidino-2-phenylindole; TDLU, terminal duct-lobular unit.
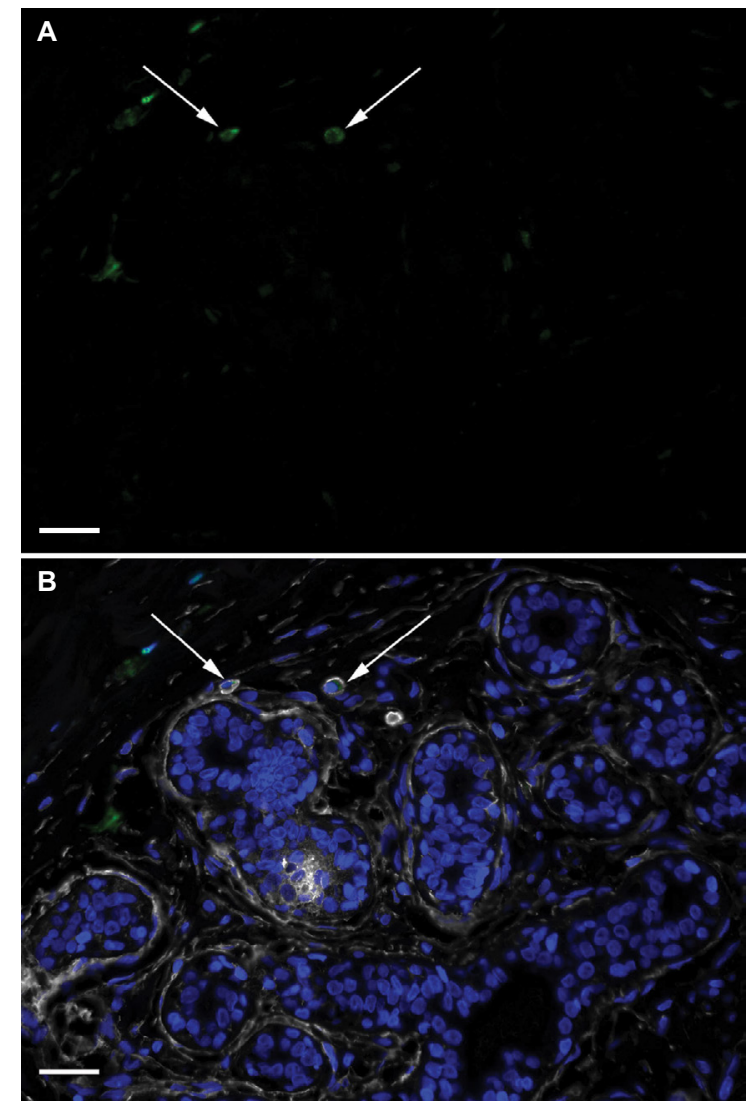

Figure $4 \mathrm{ALDHI}^{+}$round/oval-shaped cells in TDLU stroma.

Notes: DAPI nuclear staining (blue) and labeling of ALDHI (green), CD44 (white), and CD24 (red). (A) A single-channel image depicting ALDHI+ round/oval cells (arrows). (B) A composite image with all channels demonstrating that the ALDHI ${ }^{+}$ round/oval cells are positive for CD44 but not for CD24 (arrows). Scale bars = $20 \mu \mathrm{m}$.

Abbreviations: DAPI, 4',6-diamidino-2-phenylindole; TDLU, terminal duct-lobular unit.

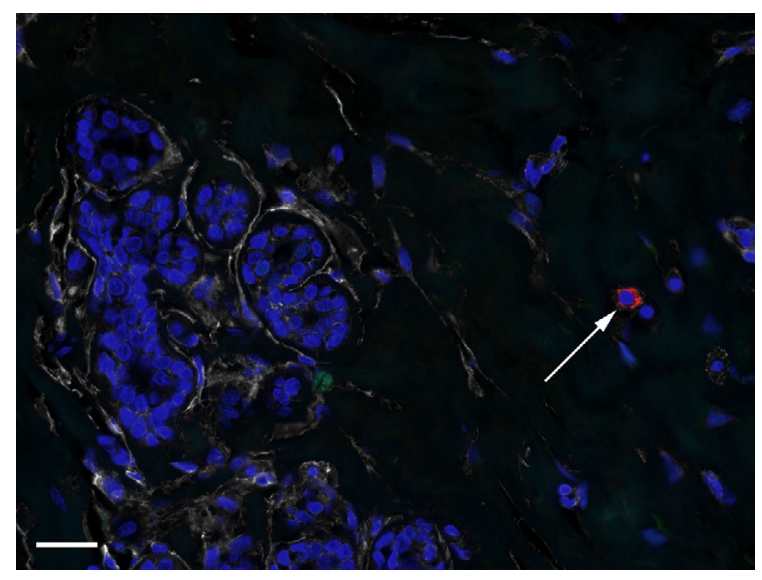

Figure 5 CD24+ cells in TDLU stroma.

Notes: DAPI nuclear staining (blue) and labeling of ALDHI (green), CD44 (white), and CD24 (red). The image depicts a CD24 cell (arrow) exhibiting no CD44 or ALDHI positivity. Scale bar $=20 \mu \mathrm{m}$.

Abbreviations: DAPI, 4',6-diamidino-2-phenylindole; TDLU, terminal duct-lobular unit. 
Table 3 Immunohistological results for the patient groups

\begin{tabular}{|c|c|c|c|c|}
\hline \multirow[t]{2}{*}{ Immunophenotype } & \multicolumn{2}{|c|}{ Spindle-shaped/polygonal cells } & \multicolumn{2}{|l|}{ Round/oval cells } \\
\hline & $\mathrm{ALDHI}^{+} \mathrm{CD}_{4}{ }^{+} \mathrm{CD}^{-} 4^{-}$ & ALDHI+ CD44- CD24- & $\mathrm{ALDHI}^{+} \mathrm{CD}^{+} 4^{+} \mathrm{CD}^{-} 4^{-}$ & $\mathrm{ALDHI}^{+} \mathrm{CD}^{-} 4^{-} \mathrm{CD}^{-} 4^{-}$ \\
\hline Family history $(n=2 I)$ & 19 (90\%) & $16(76 \%)$ & $6(29 \%)$ & $2(11 \%)$ \\
\hline No family history $(n=19)$ & 18 (95\%) & $14(74 \%)$ & $12(63 \%)$ & $2(10 \%)$ \\
\hline$B R C A /$ mutation $(n=17)$ & 15 (88\%) & $12(7 \mid \%)$ & $6(35 \%)$ & $2(12 \%)$ \\
\hline No $B R C A /$ mutation $(\mathrm{n}=23)$ & $22(96 \%)$ & $18(78 \%)$ & $12(52 \%)$ & $2(9 \%)$ \\
\hline Nulliparous $(\mathrm{n}=20)$ & $18(90 \%)$ & $12(60 \%)$ & $10(50 \%)$ & I (5\%) \\
\hline Parous $(n=18)$ & 17 (94\%) & 17 (94\%) & $6(33 \%)$ & $3(17 \%)$ \\
\hline Age $<28$ years $(n=19)$ & I7 (89\%) & 14 (74\%) & $9(47 \%)$ & $2(11 \%)$ \\
\hline Age $\geq 28$ years $(n=2 I)$ & $20(95 \%)$ & $16(76 \%)$ & $9(43 \%)$ & $2(11 \%)$ \\
\hline
\end{tabular}

Note: The table presents the number of patients in each clinical category whose sample contained "any" cells exhibiting the investigated immunophenotypes.
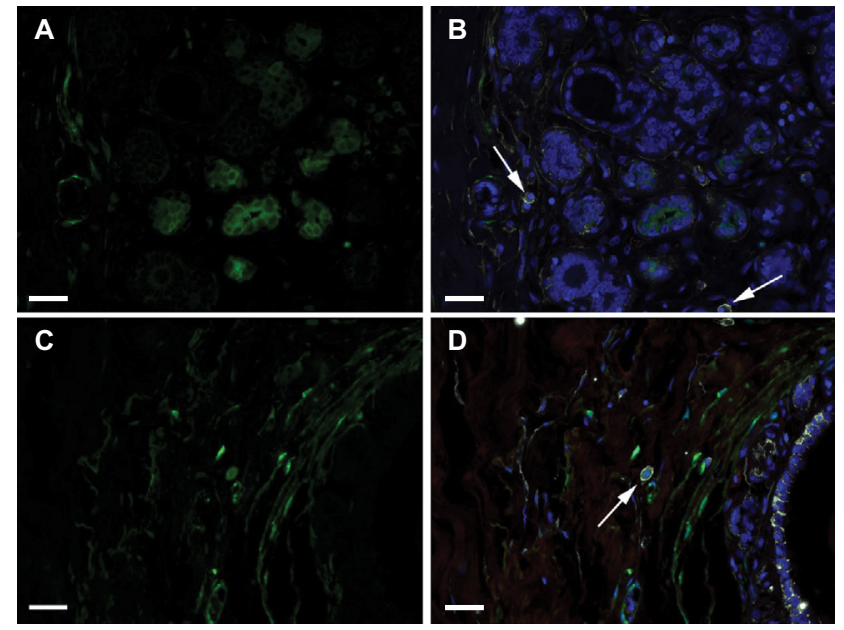

Figure 6 Round/oval cells according to family history.

Notes: DAPI nuclear staining (blue) and labeling of ALDHI (green), CD44 (white), and CD24 (red). (A)-(B) Images showing the absence of ALDHI ${ }^{+}$CD44 $4^{+}$CD24round/oval cells in a TDLU from a woman with a family history of breast cancer. Arrows indicate $\mathrm{ALDHI}^{-} \mathrm{CD} 44^{+} \mathrm{CD} 24^{-}$cells. (C)-(D) Images illustrate an $\mathrm{ALDHI}{ }^{+}$ CD44 ${ }^{+}$CD24- round/oval-shaped cell (arrow) in a TDLU from a woman with no family history of breast cancer. (A) and (C) show only the ALDHI ${ }^{+}$channel, and (B) and (D) show all four channels merged. Scale bars $=20 \mu \mathrm{m}$.

Abbreviations: DAPI, 4',6-diamidino-2-phenylindole; TDLU, terminal duct-lobular unit.

\section{$\mathrm{ALDHI}^{+} / \mathrm{CD}_{4} 4^{+} / \mathrm{CD} 24^{-}$cells}

Round/oval stromal cells with the $\mathrm{ALDH} 1^{+} / \mathrm{CD} 44^{+} / \mathrm{CD} 24$ immunophenotype were present in the TDLU stroma of specimens from six of the 21 women with a family history of breast cancer (Figure 6A and B) and from eleven of the 19 women without a family history (Figure 6C and D; two-tailed Fisher's exact test, $P=0.055$; two-tailed Spearman's rho test, $P=0.028$ ). Spindle-shaped/polygonal cells with this immunophenotype showed no associations or correlations with risk factors.

\section{$\mathrm{ALDHI}^{+} / \mathrm{CD}^{-} 4^{-} / \mathrm{CD} 24^{-}$cells}

Spindle-shaped/polygonal stromal cells with the $\mathrm{ALDH}^{+} /$ CD44-/CD24- immunophenotype (Figures 2, 3, and 6) were present in specimens from 12 of the 20 nulliparous women and from 17 of the 18 parous women (two-tailed Fisher's exact test, $P=0.021$; two-tailed Spearman's rho test, $P=0.009$ ). No associations or correlations with breast cancer risk factors were found for round/oval cells with this immunophenotype.

\section{ALDHI-/CD44 $/$ CD24- cells}

Spindle-shaped/polygonal stromal cells with the ALDH1-/ CD $44^{+} / \mathrm{CD} 24^{-}$immunophenotype were found in 35 specimens (87\%), and round/oval cells with this immunophenotype were observed in 26 specimens (65\%). No associations or correlations were found between these cell types and breast cancer risk factors.

\section{Discussion}

The current study aimed to morphologically identify ALDH1 cell types in histologically normal breast stroma and to investigate their SC characteristics, ie, their expression of CD24 and CD44. We identified two morphologically different types of ALDH1-expressing cells in the stroma of histologically benign female breast tissue, which we designated spindle-shaped/ polygonal cells and round/oval cells. The absence of stromal $\mathrm{ALDH}^{+}$cells was noted more often in patient groups with risk factors for breast cancer than in the group with no known risk factors for such disease. This indicates that the presence of $\mathrm{ALDH}^{+}$cells in breast stroma might be a beneficial factor in the context of cancer risk. However, although ALDH1 is a marker for SCs, the mentioned findings should not be interpreted as a suggestion that SCs in stroma protect against breast cancer, because most $\mathrm{ALDH}^{+}$cells are in fact not SCs. ${ }^{3,10,11}$

A significant number of specimens from the nulliparous patients lacked $\mathrm{ALDH}^{+} / \mathrm{CD} 44^{-} / \mathrm{CD} 24^{-}$spindle-shaped/ polygonal cells, indicating a relation to cancer risk since nulliparity is a known risk factor for breast cancer. ${ }^{12}$ This finding is also interesting considering that it was recently observed that $\mathrm{ALDH}^{+}$cells of spindle or polygonal shape are frequently absent in stroma of histologically normal mucosa of patients with bladder cancer. ${ }^{10}$ 
The round/oval cells with the putatively stringent SC immunophenotype $\mathrm{ALDH} 1^{+} / \mathrm{CD} 44^{+} / \mathrm{CD} 24^{-}$were often absent in TDLU stroma of patients with a family history of breast cancer. Such cells had mononuclear leukocyte-like morphology with a granular cytoplasm and thus resembled mast cells. A previous evaluation of the same material indicated that $\sim 50 \%$ of ALDH $1^{+}$round/oval cells in stroma were negative for the pan-leukocyte marker CD45. ${ }^{6}$ These cell types thus correspond to the recently described morphology of mesenchymal SCs of the multilineage-differentiating stress-enduring (Muse) type,${ }^{5}$ which was discerned using markers other than those employed in the present study. It remains to be determined whether $\mathrm{ALDH}^{+} / \mathrm{CD}_{4} 4^{+} / \mathrm{CD} 24^{-}$round/oval cells in breast stroma are actually mesenchymal SCs.

It has been observed that stromal ALDH1 expression is lower in malignant breast tumors than in benign conditions, ${ }^{13,14}$ and stromal ALDH1 expression in malignant tumors has been found to be associated with better survival. ${ }^{15}$ Our earlier study of ALDH1 $1^{+}$ductular cells located in areas of benign breast tissue did not reveal any statistically significant association with concurrent cancer. ${ }^{7}$ The current investigation of benign breast tissue did not address ALDH1 expression in patients with cancer per se due to the low number of subjects.

\section{Conclusion}

In this study, spindle-shaped/polygonal and round/oval $\mathrm{ALDH}^{+}$cells were absent in benign stroma of a significant number of women at risk of breast cancer. The round/oval cell type carried the putatively stringent SC immunophenotype $\mathrm{ALDH} 1^{+} / \mathrm{CD} 44^{+} / \mathrm{CD} 24^{-}$, whereas the spindle-shaped polygonal cells did not. The low presence of ALDH1 ${ }^{+}$cells in benign mammary stroma of women at risk of breast cancer agrees with recently reported data indicating that high ALDH1 expression in breast cancer stroma is an independent favorable prognostic marker. The associations and correlations found in the current study of ALDH1 ${ }^{+}$stromal cells are the reverse of what our group has previously observed regarding $\mathrm{ALDH1}^{+}$epithelial cells, which emphasizes the need to address epithelial and stromal cells separately, and also underlines the importance of histological correlation. Clearly, multi-antibody in situ investigations need to be performed to further elucidate the relationship between SC markers and the risk of breast cancer.

\section{Acknowledgments}

This study was supported by grants from the Swedish Cancer Society, the Swedish Research Council, and Skåne University Hospitals. The authors also acknowledge financial support from the European Research Council (Advanced Grant ERC2011-294576). The authors thank ImaGene-iT AB (Lund, Sweden) for experimental support, LRI AB (Lund, Sweden) for support with microscope equipment, and Patricia Ödman for language editing.

\section{Author contributions}

All the authors contributed to conceiving and designing the experiments. $\mathrm{HO}$ and $\mathrm{HJ}$ contributed to patient data. BLI performed the experiments. BLI analyzed the data. BLI wrote the paper. All the authors contributed to the critical revision of the paper and accepted the final version.

\section{Disclosure}

The authors report no conflicts of interest in this work.

\section{References}

1. Hongbao M, Shen C. Review of stem cell studies. Nat Sci. 2007;5:45-65

2. Al-Hajj M, Wicha MS, Benito-Hernandez A, Morrison SJ, Clarke MF. Prospective identification of tumorigenic breast cancer cells. Proc Natl Acad Sci U S A. 2003;100(7):3983-3988.

3. Ginestier C, Hur MH, Charafe-Jauffret E, et al. ALDH1 is a marker of normal and malignant human mammary stem cells and a predictor of poor clinical outcome. Cell Stem Cell. 2007;1(5):555-567.

4. Yoshioka T, Umekita Y, Ohi Y, et al. Aldehyde dehydrogenase 1 expression is a predictor of poor prognosis in node-positive breast cancers: a long-term follow-up study. Histopathology. 2011;58(4):608-616.

5. Wakao S, Kitada M, Kuroda Y, et al. Multilineage-differentiating stress-enduring (Muse) cells are a primary source of induced pluripotent stem cells in human fibroblasts. Proc Natl Acad Sci U S A. 2011;108(24):9875-9880.

6. Isfoss BL, Holmqvist B, Alm P, Olsson H. Distribution of aldehyde dehydrogenase 1-positive stem cells in benign mammary tissue from women with and without breast cancer. Histopathology. 2012;60(4):617-633.

7. Isfoss BL, Holmqvist B, Jernström H, Alm P, Olsson H. Women with familial risk for breast cancer have an increased frequency of aldehyde dehydrogenase expressing cells in breast ductules. BMC Clin Pathol. 2013;13(1):28.

8. Liu S, Wang D, Sun Y, et al. Breast cancer stem cells transition between epithelial and mesenchymal states reflective of their normal counterparts. Stem Cell Rep. 2014;2(1):78-91.

9. Honeth G, Lombardi S, Ginestier C, et al. Aldehyde dehydrogenase and estrogen receptor define a hierarchy of cellular differentiation in the normal human mammary epithelium. Breast Cancer Res. 2014;16(3):R52.

10. Friedman SL. Hepatic stellate cells: protean, multifunctional, and enigmatic cells of the liver. Physiol Rev. 2010;88(1):125-172.

11. Isfoss BL, Busch $\mathrm{C}$, Hermelin $\mathrm{H}$, et al. Stem cell marker-positive stellate cells and mast cells are reduced in benign-appearing bladder tissue in patients with urothelial carcinoma. Virchows Arch. 2014;464(4):473-488.

12. Kelsey JL, Gammon MD, John EM. Reproductive factors and breast cancer. Epidemiol Rev. 1993;15(1):36-47.

13. Resetkova E, Reis-Filho JS, Jain RK, et al. Prognostic impact of ALDH1 in breast cancer: a story of stem cells and tumor microenvironment. Breast Cancer Res Treat. 2010;123(1):97-108.

14. Schwartz T, Stark A, Pang J, et al. Expression of aldehyde dehydrogenase 1 as a marker of mammary stem cells in benign and malignant breast lesions of Ghanian women. Cancer. 2013;119(3):488-494.

15. Bednarz-Knoll N, Nastaly P, Zaczek A, et al. Stromal expression of ALDH1 in human breast carcinomas indicates reduced tumor progression. Oncotarget. 2015;6(29):26789-26803. 


\section{Publish your work in this journal}

Breast Cancer - Targets and Therapy is an international, peerreviewed open access journal focusing on breast cancer research, identification of therapeutic targets and the optimal use of preventative and integrated treatment interventions to achieve improved outcomes, enhanced survival and quality of life for the cancer patient.
The manuscript management system is completely online and includes a very quick and fair peer-review system, which is all easy to use. Visit http://www.dovepress.com/testimonials.php to read real quotes from published authors.

Submit your manuscript here: https://www.dovepress.com/breast-cancer---targets-and-therapy-journal 